\title{
Sustainable Development of Seaport Cities through Circular Economy: A Comparative Study with Implications to Suez Canal Corridor Project
}

\author{
Ahmed Mohamed Ezzat ${ }^{0}$
}

\begin{abstract}
:
As seaport cities have large potential for commercial, tourist and industrial activities, they are considered one of the main driving forces of economic growth. At the same time, the localization of these activities in seaport cities can be a source of new economic, social and ecological damage for the whole seaport city system. Accordingly, the development of the seaport city system tends to become less sustainable despite the growing trend to focus on sustainable development through ensuring sustainable consumption and production patterns.

The study focuses on adopting the circular economy model in seaports cities as a mean to enhance sustainable development. The study used the analytical method showing the theoretical preview of circular economy, the potential opportunities of adopting circular economy and the comparative method to show the best practices of circular economy in seaport cities. Then the results were used to evaluate the Suez Canal Corridor Project. Both theoretical and empirical best practices stressed the rule of adopting a circular economy model in supporting seaport cities sustainable development. The conclusion for the Suez Canal Corridor Project was that some of the dimensions of the circular economy model are missing including the legislative, institutional and cultural issues. Those can be considered as challenges to the contribution of the project to bring sustainable development.
\end{abstract}

Keywords: Port sustainable Development, Development of seaport cities, Greening the economy, the circular economy model and the Suez Canal Corridor Project.

\section{Introduction}

As seaport areas and coastal cities have significant potential for industrial projects, they have a particular development potential. At the same time, they should pay attention to pollution prevention, resources and waste management, and minimizing environmental costs in order to enhance seaport sustainable development and competitiveness. Port sustainable development can be defined as the ability of meeting its needs without endangering its own future. If coastal cities are serious in their attempt to launch a sustainable development model, circular thinking can be adopted.

Egypt started the development of the Suez Canal corridor as a mega national project aimed at encouraging sustainable development through developing three major regions along the banks of Suez Canal (figure 1 illustrates the location of the project). This paper targets studying the project proposal compared to the best practices in ports cities that succeeded to support sustainable development depending on the use of the circular economy model.

\footnotetext{
${ }^{0}$ College of International Transport \& Logistics, Arab Academy for Science, Technology and Maritime Transport, Cairo, Egypt.
} 


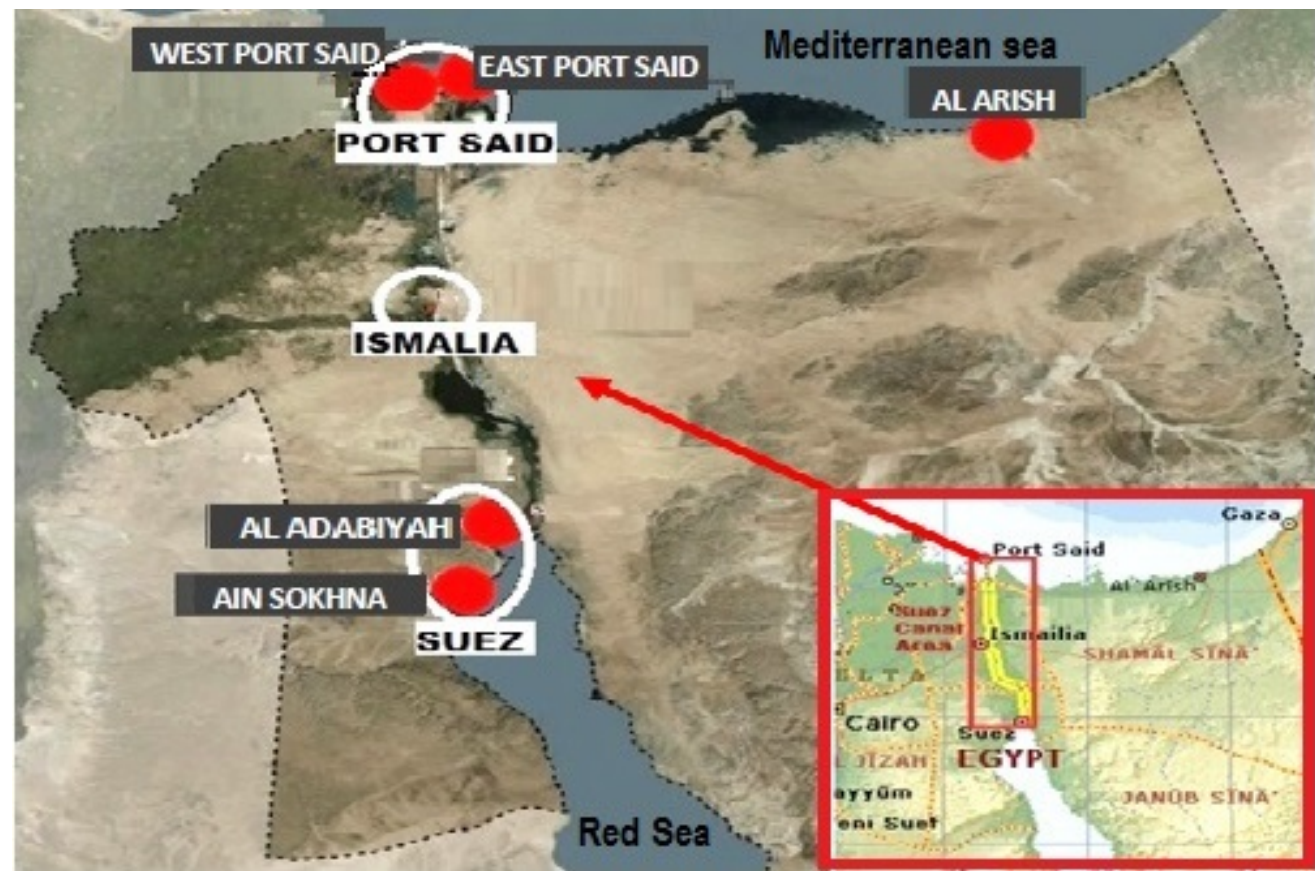

Figure 1: The Suez Canal Zone. Source: The Technical Secretariat for the Suez Canal Corridor Development - SCC.

In order to achieve its goals, the paper studies an overview on the circular economy model in section two. In section three, the theoretical preview of circular economy is analyzed. The potential opportunities of adopting circular economy are studied in section four. Then in section five, the best practices of circular economy in seaport cities are analyzed. Finally in section six, the Suez Canal Corridor Development Project is evaluated from the circular economy perspective. The paper is ended up by conclusions and recommendations.

\section{An overview on circular economy model}

The concept of "circular economy" has its roots in the industrial environment (Rizos, Behrens, Kafyeke, Hirschnitz-Garbers, \& Ioannou, 2015). The circular economy model can be defined as "restructuring the industrial systems to support ecosystems through the adoption of methods to maximize the efficient use of resources by recycling and minimizing emissions and waste" (Preston, 2012). Accordingly, while a traditional "take-make-use-dispose" linear economy model $^{1}$ relies on large quantities of cheap, easily accessible materials and energy in addition to resulting in massive waste, a circular economy model represents a development strategy that enables economic growth while optimizing the consumption of natural resources, deeply transforming production chains

\footnotetext{
${ }^{1}$ Where raw materials are turned into products which are destroyed after use as they have no economic value after use. The basic principles of this is called "linear model of economy".
} 
and consumption patterns and re-designing industrial systems ${ }^{2}$ ("Growth within: a circular economy vision for a competitive Europe", 2015). The difference between linear economy and circular economy models is shown in figure 2.

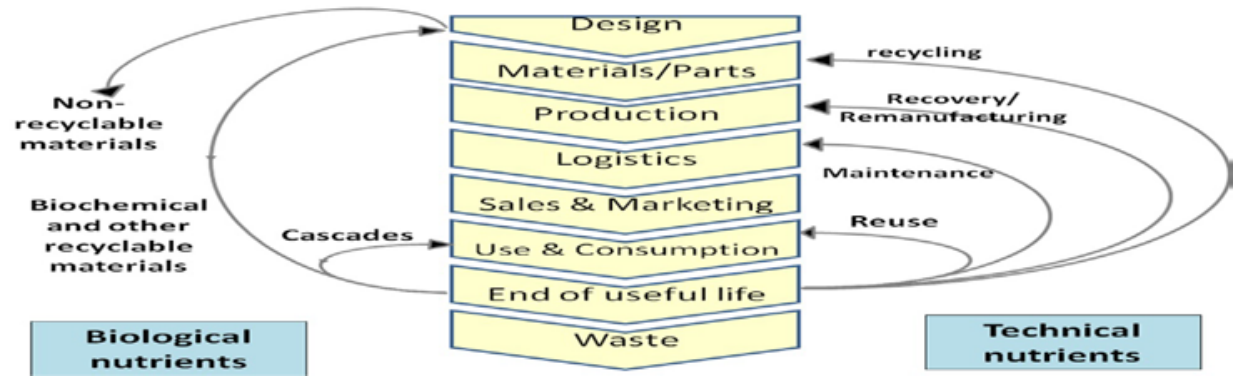

Figure 2: Linear economy vs. circular economy. Source: (Stegeman, 2015)

The central axis of the graph shows the linear production process which we called linear economy. The arrows indicate the possibilities for circularity with respect to the reuse and recycling of resources, waste, other materials and products. The ultimate goal is to remove the last arrow (waste) completely. Accordingly, a circular economy model goes beyond the pursuit of waste prevention and waste reduction to inspire technological, organizational, and social innovation throughout the value chain in order to "design out" waste from the beginning, rather than relying solely on waste recycling at the end of the chain ("Growth within: a circular economy vision for a competitive Europe", 2015; Rizos et. al, 2015). The system diagram in figure 3 illustrates the continuous flow of technical and biological materials through the value circle.

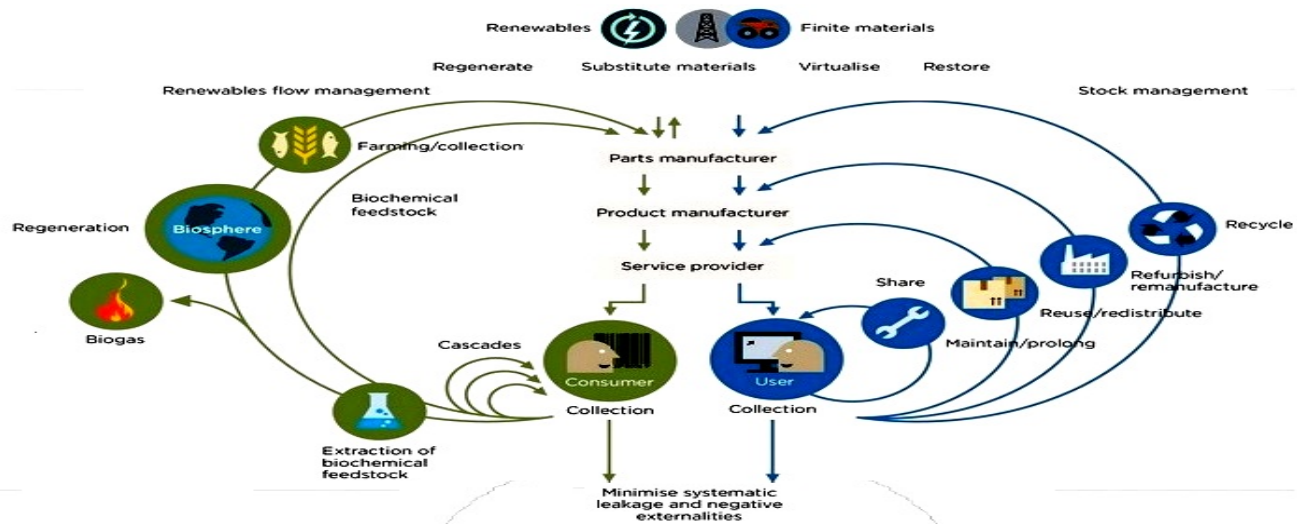

Figure 3: Circular economy systems diagram. Source: ("Circular Economy System Diagram”, 2015)

It is clear from the figure that the basis of the circular economy model is the remanufacturing of products through the usage of renewable energy, in particular solar

\footnotetext{
${ }^{2}$ As in circular economy products do have value not only after use but during the production process because they would return to nature without problems and cost.
} 
power and eliminating waste as the system is designed to use waste as a resource.

There are four main principles of the circular economy model ("Growth within: a circular economy vision for a competitive Europe", 2015; Rizos et al., 2015; Stegeman, 2015):

a) Considering the reuse from the design to minimize waste.

b) Using renewable sources of energy and materials.

c) Studying feedback loops within the system to optimize the production system as a whole.

d) Maximizing the usage value of products through sharing them among users and prolonging their life through the reuse, maintenance and repair.

\section{The Theoretical Preview of the Circular Economy Model}

A review of the literature shows that the focus on the concept of the circular economy model can be deduced from a number of basic concepts including:

a) Greening the economy: The concept of green economy was set by the United Nations (UN) to tackle environmental challenges through minimizing unsustainable consumption and production patterns to cope with sustainable development criteria. During the global economic crisis in 2008 governments found that only regulatory or tax policies which force or incentivize firms to invest in environmental improvements can have the same impact as spending without increasing public deficits (Allen and Clouth, 2012). This prompted Jacobs (2012) to partially explain the accelerating trend towards green growth after the 2008 financial crisis by the Keynesian model. Additionally, governments found that adopting the circular economy thinking can provide opportunities to get people into work $^{3}$ and to increase demand for a wide range of products (Beaulieu, Durme \& Arpin, 2015).

b) Natural capitalism: Hawken (1997) concluded that the free market economy does not guarantee the efficient use of resources. Additionally, the successes of industry and capitalism led to a pressure on natural resources which need changes in the operations adopted in production ${ }^{4}$. Rational corporations and societies should focus not only on the efficiency of labor and their productivity but also on the efficiency of the use of resources and energy.

c) Fundamental economy: The term fundamental economy was coined in 1986 by Walter Stahel to focus on the function or performance of products. The fundamental country's economic purpose is to manage an integrated system in order to maximize the usage value for the longest possible time and simultaneously minimize the use of material resources and energy as possible (Stahel, 1997). The roots of the theory came as a result of the inability of theories to give an evidence for the socialist economic failure which occurred in the late of the twentieth century. Friedman and Oren (1995) proved that the same incentive problems arise in the allocation of private goods especially after dropping the assumptions required for perfect competition and that the efficient allocation of private goods can be enhanced through supporting the environmental issues.

d) Life cycle thinking: The traditional focusing on production gave a very narrow scope of

3 Mundaca and Richter (2015) indicated that the green energy stimulus programs have had a positive effect on the American economy. Strand and Toman (2010) classified the most beneficial green programs in times of crisis on short run employment effects, long-run growth effects, effects on carbon emissions, and "cobenefit" effects on the environment, natural resources, and for other externalities.

4 This is because the conventional economic theories do not put natural capital into account during measuring performance and success. 
the environmental impacts of a product. Accordingly, studies started focusing on life cycle thinking which takes the focus away from production and puts it on the product. Life cycle thinking targets reducing the use of resources, the emissions to the environment and improving product's socio-economic performance throughout the life cycle (Beaulieu et al., 2015).

e) Creating Shared value principle: This principle focuses on the integration between business and society through studying how business choices can benefit both business and society (Porter and Kramer, 2006). The shared value principle has its roots from the need of business to a successful community, not only to create demand for its products but also to provide critical public assets and a supportive environment. At the same time a community needs successful businesses to provide jobs and wealth creation opportunities for its citizens. Therefore the principle includes policies and operating practices that enhance the competitiveness of a company and simultaneously add social and environmental value for the society in which it operates.

f) Resource and energy efficiency gap: Economists recognized a long time ago that market conditions may depart from efficiency if there are market failures. The later coupled with the ignorance of environmental externalities lead to inefficiently pricing and use of energy (Gerarden, Newell, \& Stavins, 2015). This put pressure on governments to affect institutions whether directly or indirectly to enhance an efficient use of energy and resources. This leads economic literature on energy efficiency to search for visualizing energy efficiency decision making through identifying the degree of market or behavioral failures and the opportunity for policy interventions to add net benefits (Gillingham, Newell, \& Palmer, 2009). Accordingly, policy makers started responding by targeting improving economic efficiency through adopting practices that can successfully reduce both market and behavioral failures.

g) Ecological Transition: The traditional macroeconomics focused on the health of the national economy through adopting reasonable economic growth coupled with securing employment assuming that other issues like the care for the environment are included. Then efforts and initiatives on both national and global perspectives started focusing on the ecological transition and its effects on the sustainability of the health of national economies ${ }^{5}$. Hence, researches started focusing on the development of an ecological macroeconomics and the sustainability of long-term macroeconomic growth (Harris, 2009).

\section{The Potential Opportunities of Adopting a Circular Economy Model}

Satisfying the basic principles of the circular economy model can enhance sustainable development from both the national and micro levels ${ }^{6}$. From the national level, the opportunities of adopting a circular economy model are reflected as a result of the efficient use of resources and energy which leads to accelerating economic growth. The main channels which benefits the macro economy through adopting a circular economy model are saving in net material costs, enhancing researches and innovations,

5 Ecological transition refers to moving from the current mode of production and consumption to a more environmental one.

6 This does not mean that there are no losers during the transition period. The reason is that although more goods are reused and repaired which is considered opportunities for a group of people, fewer new goods are bought, which implies a loss of income for certain product manufacturers and transporters. 
encouraging the multiplier effect ${ }^{7}$, increasing employment opportunities in both numbers and conditions, reducing budget pressure through taxing non-recycling activities and generate revenues from household waste, reducing negative externalities and climate change mitigation ("Growth within: a circular economy vision for a competitive Europe”, 2015; Rizos et al., 2015).

On the other hand, from the micro level, the opportunities are generated from the engaged practices and their effects on both of businesses and households. Firstly from the business side the benefits include savings in net material cost and improving security of supply, fighting the volatility in prices of resources, improving product quality and company's reputation, enhancing competitiveness and technological progress, increasing employees' loyalty, improving customer interaction and loyalty and enhancing goodwill between businesses and authorities. Secondly from the household's side the benefits include greater utility to customers and an increase in real incomes as a result of the price reduction (Rizos et al., 2015; Walendowski,Roman, \& Miedzinski, 2014).

\section{The Best Practices of a Circular Economy Model in Seaport Cities}

Putting into consideration the diversity of seaports and seaport cities ${ }^{8}$, a universal action plan during the transition towards circular economy model does not exist. Accordingly, setting the best practices during the transition period in this study is done by going in two directions. The first is to study a general framework of the guiding principles of moving towards a circular economy model in seaports in the literature. The second is to study the empirical best practices of cases succeeded during the transitional period.

\subsection{A literature review of the transition management towards a circular economy model}

The main economic barriers during the transition towards a circular economy model are the low prices of primary materials ${ }^{9}$; ignoring external costs; the relatively high investment costs of establishing a circular economy model in the short term while the yields do not become apparent until the longer term. Accordingly, several tasks from macro, sectoral and micro levels are needed to eliminate the barriers during the transition (Girard, 2013; Kok, Wurpel, \& Ten Wolde, 2013; Merk and Dang, 2013; Rizos et al., 2015; Walendowski et al., 2014).

Firstly, from the macro level, governments have to play preventive, curative and awareness roles to enhance closing the loop of product lifecycles, including:

7 Adopting the circular economy model leads to the creation of a new type of economic activities in addition to enhancing employment and capital productivity, all of which are important multipliers in the economy.

8 Seaports have different functions, layout, volumes, and surfaces that make every seaport and seaport-city different. Additionally, seaport-cities differ in the size of urban or regional population, the size of port traffic, and the connectivity to the seaport.

9 The low prices of primary raw materials make it less profitable for recycled materials. 
(1) Studying the new ecosystem and measuring the gap then setting a plan to fill in the gap.

(2) Setting strong alliances to support the transition and face the resistance to change.

(3) Supporting investments in circular innovation to implement circular business models.

(4) Putting an ambitious and reliable long-term path for waste management and recycling.

(5) Reviewing related legislations in order to enhance the sustainability of development.

(6) Leading the transition through widespread implementation of green public procurement.

(7) Integrating the circular economy model principles in education and training programs ${ }^{10}$.

(8) Implementing new economic indicators to reflect externalities.

Secondly, from the micro level, seaports and related institutions should support:

(1) Having a Long term strategic seaport plan targets adopting a circular economy model.

(2) Developing a long-term port vision identifying the opportunities of having a circular economy model and guiding the short-term actions.

(3) Upgrading port workers' skills to maximize the benefits of moving towards smart ports.

(4) Focusing on improving port performance through innovation policies.

(5) Setting up a simple index for circular performance that can give weights to social and environmental externalities in addition to financial accounting in decision-making.

Although the previous tools are necessary during the process of the transition towards a circular economy model, strengthening partnerships and adopting a package of some of these tools as complementary tools are essential for the success of the transition towards a circular economy model (Walendowski et al., 2014).

\subsection{The best practices in seaports succeeded during the transitional period}

Two case studies of seaports which succeeded to move towards the circularity of activities are studied. The first is the port of Rotterdam (Europe's largest seaport) and the second is Ningbo port, china (where advancing circularity is top-down driven) (Merk, 2013).

\subsubsection{The circular economy model in the port of Rotterdam, Netherlands}

The port of Rotterdam is Europe's largest seaport. The vision of the port of Rotterdam in 2030 includes the ambition to be the most sustainable port of its kind in the world through having greener industry and logistics to enhance the quality of the environment. Accordingly, the port authority presented a sustainability map shows a selection of 15 sustainable initiatives.

10 Such as including system thinking to address the lack of awareness and sense of urgency move towards the circular economy model. 


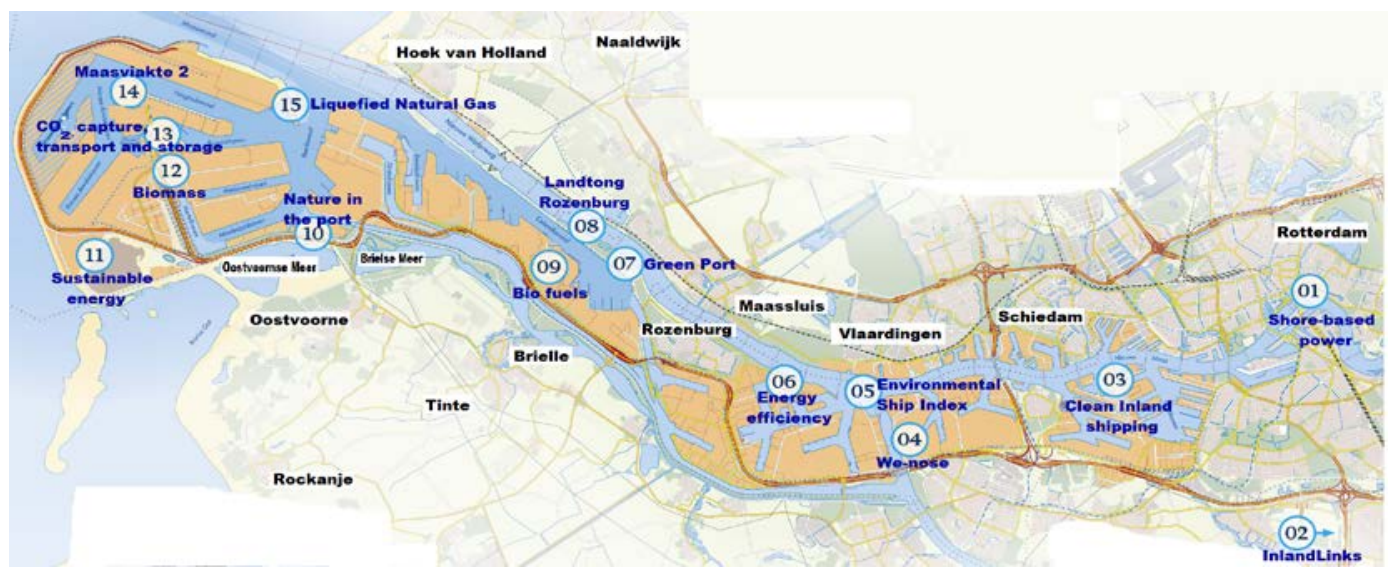

Figure 4: The port of Rotterdam sustainability map

Source: The port of Rotterdam official website (bttps:/ / mmw.portofrotterdam.com/ en/ the-port/sustainability)

Working on its vision, port authorities adopted several projects, as shown in figure 4, like (Girard, 2013; Hiranandani, 2012; Kok et al., 2013; Merk, 2013; Merk and Dang, 2013):

(1) Sustainable energy generation project Solar, wind and bio fuels became main sources of energy (the $9^{\text {th }}, 11^{\text {th }}$ and $12^{\text {th }}$ initiatives in figure 4 ) in addition to coal and natural gas $^{11}$.

(2) Using liquefied natural gas as a fuel for seagoing vessels as an alternative fuel for seagoing vessels, inland vessels and trucks (the $15^{\text {th }}$ initiative in figure 4 ). This lowers emission of nitrogen oxides and $\mathrm{CO}_{2}$ and reduces the need for engines maintenance.

(3) Having strict requirements in terms of sustainability for companies wishing to locate on the port and industrial areas, especially the new port and industrial area of Maasvlakte 2 ((initiatives numbers $6^{\text {th }}, 13^{\text {th }}$ and $15^{\text {th }}$ in figure 4) (Kippenberger, 2012).

(4) Enhancing the possibility of removing waste from the port and docks to improve the quality of life (the $7^{\text {th }}$ initiative in figure 4).

(5) Providing traders with online route planner for logistics service providers through setting out the most sustainable and efficient route to and from the port of Rotterdam (the $2^{\text {nd }}$ initiative in figure 4).

(6) Supporting the use of cleaner engines. Port authorities grant a discount on the inland port tariffs if vessels have cleaner engines. Additionally, they established an index called Environmental Ship Index (the $5^{\text {th }}$ initiative in figure 4) shows the environmental score with respect to the legal requirements on a scale of 0 to 100 (Kok et al., 2013). Ships scoring 31 or higher receive a 10\% discount on port tariff.

(7) Establishing a green area of nature outside the port which reinforces the ecological value of the area (the $7^{\text {th }}$ and $10^{\text {th }}$ initiatives in figure 4 ). Additionally, the port has sensors to measure any changes in air's composition (the $4^{\text {th }}$ initiative in figure 4).

(8) Promoting the port as an interesting area for scientific research in addition to

11 The total capacity of wind turbines installed in the Rotterdam port area is about 10 per cent of the total wind energy capacity in the Netherlands and the port authority targets to double wind energy generated in public port areas by 2020 . Additionally, this energy can be used to supply power to ships. 
continuous education programs in six educational stages from primary school to university for people interested in the port.

Additionally, The Netherlands leads the European Commission to publish a circular economy package, consisting of proposals for waste legislation and an EU circular economy action plan in the first half of 2016 (Kippenberger, 2012).

\subsubsection{The circular economy model in The Ningbo port, China}

Ningbo is a port city, located mainly in Beilun district, in south of Shanghai. The industrial port areas of Ningbo mainly dominated by petrochemical industries and heavy industrial base including iron and steel industry, chemical industry, pulp and paper industry, power plants and automotive industries (Shi, Dong, \& Wu, 2015). These industries bring huge resource and environmental burdens to Beilun. This leads Beilun since 2005 to target a sustainable development strategy through adopting a circular economy model. This leads Beilun in 2008 to be awarded as the best district in advancing circularity in Zhejiang Province. In 2013, Beilun listed as a role model of circular economy in the industrial parks (Merk, 2013). Several factors supported Beilun to succeed in its transition during advancing circularity such as (Merk, 2013; Shi et al., 2015):

(1) Moving towards circularity is a trend in China: This happened as a result of concerted combination of factors, including:

(a) According to Chinese development plan, to 2020 the GDP will be two times its level in 2000 although Chinese energy and resources will not help in reaching that goal using the traditional linear economy approach. Accordingly, China focuses on circularity in order to use the available resources efficiently.

(b) China is one of the main countries who suffer from green barriers. This leads China to carry out clean production which became a trend in the country.

(c) Traditional growth pattern has caused series ill effects in China because of air and water pollution.

(2) Establishing the legal framework: China enacted a law on promotion of cleaner production and another on energy saving.

On the industry level, Beilun had several steps during the transition towards a circular economy model, including:

(1) The evolution of energy infrastructure: As a step towards advancing circularity, Beilun started using liquefied natural gas imported from Indonesia and other countries in addition to building a garbage power plant in 2008 and a wind mill farm in 2013 instead of importing coal from Qinhuangdao and other north portal cities in China.

(2) Establishing a sound water cycle network: They integrated all types of water resources, including piped water, industrial water, reclaimed water and other water resources to be provided directly to power plants, iron and steel plants and other large industrial users.

(3) Focusing on cultural issues to improve the quality of life for local residents: Authorities started the Ningbo Cultural Plaza project in eastern Ningbo's development town. 
(4) Adopting a system thinking method of planning integrated industries: In planning the system, authorities studied the relationships of dependency and feedback loops exist which contribute to the resilience of the circular economy model. This is clear from figure 5 .

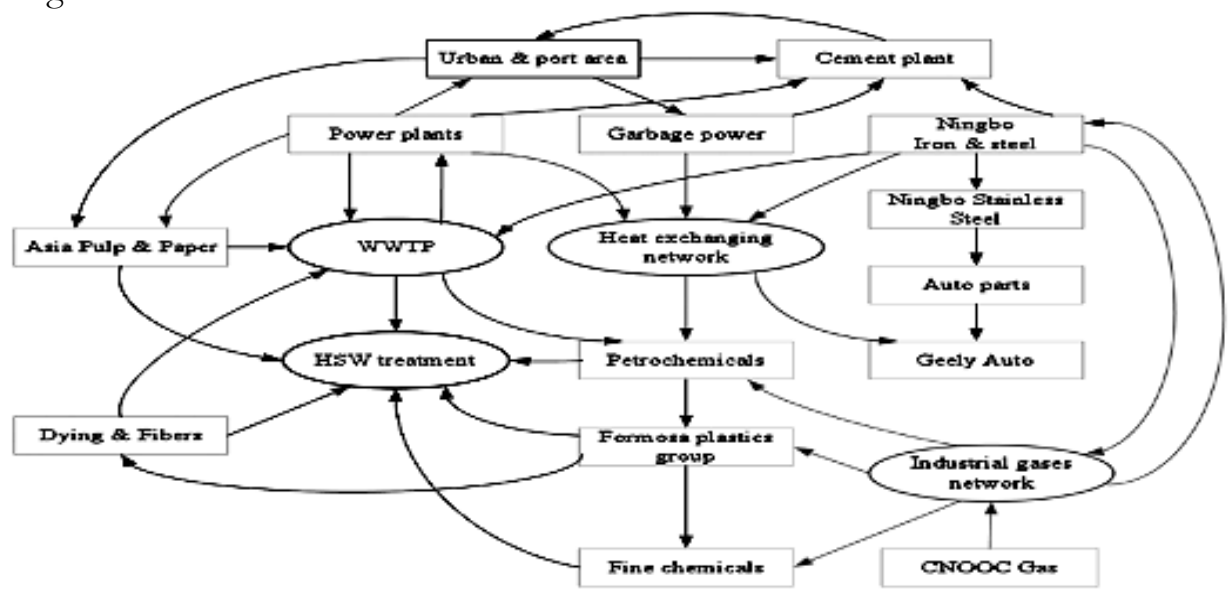

Figure 5: Beilun circular economy system. Source: (Shi et al., 2015)

Accordingly, from studying the case of the port of Ningbo, we concluded that the centralized planning of the port gave the planners the ability to optimize the circular economy system through integrate industries to advance circularity.

\section{Evaluating the Suez Canal Corridor Project from the Circular Economy Model Perspective}

The Suez Canal Corridor Project is a mega project in Egypt launched on August 2014 targets transforming the area of the Suez Canal into a world-class global logistics hub and industrial processing centre. Among its objectives, the government targets adopting best practices that can lead to enhance sustainable development.

The project aims to develop 3 major regions along the banks of Suez Canal. These regions are Port Said Region, Al Ismailia Region and Suez Region in three phases, over a period of 20 years. In the first phase, Ports of Port Said and Suez will be transformed into global warehouses. Additionally, a container terminal as well as shipyard will be built and a new wave breaker, railways, dock walls, and telecommunications equipment will put in place. The second phase includes establishing an industrial zone to host industries such as textiles, packaging factories, machinery, building supplies, and ship maintenance centers in addition to light tourism. The third phase will set up a technology center in Ismailiya (El-Asmar, Taha, El-Kafrawy, \& El-Sorogy, 2015). The proposed projects in the 3 regions are shown in figure 6. 


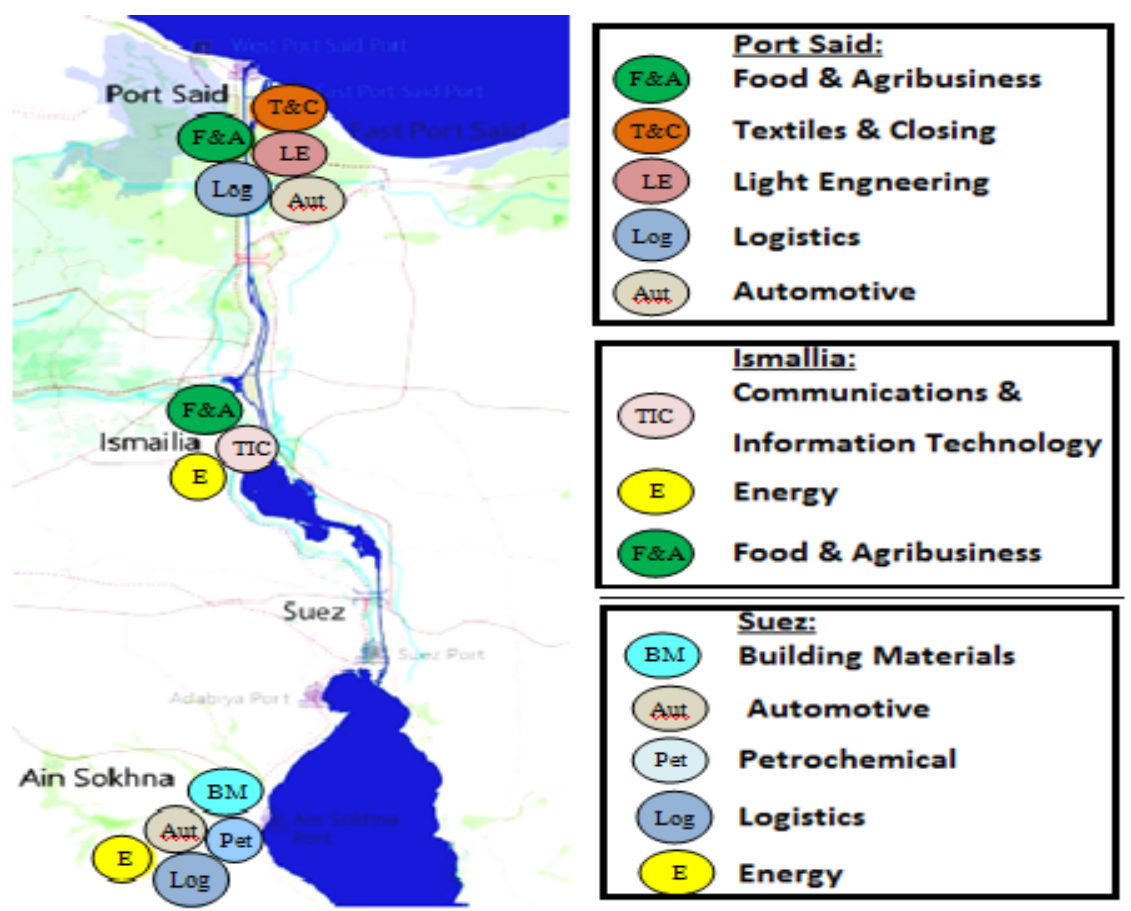

Figure 6: The Development Zones in the Suez Canal Corridor Project. Source: The Technical Secretariat for the Suez Canal Corridor Development - SCC

The General Authority for the Suez Canal Economic Zone announced that the planned project targeted three directions. The first is to enhance manufacturing in the three regions. The second is to facilitate transportations around the development zone. The last is to reduce negative effects of the concentration of industries and supportive activities in the three regions through adopting some ecological projects. For the purpose of the study the third direction which is related to the ecological projects is studied.

In order to enhance its role to support sustainable development in the region and putting into consideration the centralization of manufacturing activities, planners supported having some ecological projects in the three major regions as follow:

a. Wind farms to supply renewable power to the Suez Canal Zone to develop the site as an eco-tourism destination. The proposed location for the project is in Rural Suez (Ras Sedr).

b. Solar photovoltaic Fields in order to supply renewable power in Egypt, it is proposed to establish solar farms in East Ismailia and Rural Suez.

c. Waste to energy incineration plants. Four locations are proposed in East Port Said, ElArish, Qantara and Ain Sokhna.

d. New desalination plants in order to provide long term water security to the development of the Suez Canal Zone. The proposed areas are Ain Sokhna and the North Coast of Sinai. Each project will comprise a seawater intake plant, pre-treatment facilities, desalination units, production storage and transmission line and an outfall.

e. Combined cycle gas turbine power station. Waste heat can be used to desalinate water or 
generate chilled/hot water for the district network.

f. New wastewater treatment plant and disposal system. There are proposed three areas East Port Said, East Ismailia and Ain Sokhna.

g. Provision of additional wastewater treatment capacity. In addition to the existing 4 wastewater treatment projects, new additional capacity is required after the centralization of activities in the zone. The proposed locations for new wastewater treatment plants are West Port Said, Qantara, Ismailia City and Suez City.

\subsection{The main challenges facing the Suez Canal Corridor Project from the Circularity Perspective}

The main challenges facing the project which are related to enhancing sustainable development in the project's port cities through adopting a circular economy model including:

1. Institutional barriers: Several institutional barriers restrict the transition towards a circular economy model including structural barriers that have taken root for years in daily practice which maintain the linear economy such as:

a. The current economic system: the current economic system supports the linear economy approach as it offers linear companies advantages over circular companies in areas such as taxation and competition policy.

b. Vested interests: the possible resistance to a circular economy model from those who have 'vested interests' those can restricts the transition towards the circular economy model.

c. The lack of having an indicator of progress: GDP does not take into account the sustainability of growth in an environmental and social context.

2. Legal barriers: Current legislation and regulations in Egypt support linear economy approach in many ways, including:

a. Inadequate legislative framework: According to the law, waste is not a product, not a resource. The current legislative framework does not pay attention to protecting the environment and public health.

b. The relatively low taxes on raw materials: This negatively affects the transition towards a circular economy model as it makes the repair or sorting of collected waste products expensive.

3. Economic barriers: At present, it is relatively profitable to operate linear economy approach for several reasons such as:

a. Low prices of primary raw materials.

b. External costs are not included in the costs.

4. Social barriers: The lack of awareness, knowledge and sense of urgency is one of the main barriers during the transition.

5. Limitations to knowledge and innovation: Insufficient knowledge development and innovation may impede the transition as the circular economy model actually relates to various sectors.

\section{Conclusions and Policy Implications}

The study highlighted the rule of adopting a circular economy model in enhancing sustainable development in port cities. Both theoretical and empirical best practices stressed the rule of circular economy models in supporting sustainable development in seaport cities. For the Suez Canal Corridor Development Project, some of the dimensions of the circular economy model are missing including the legislative, 
institutional and cultural issues. These are considered as challenges supporting the linear economy rather than the transition towards a circular economy model.

The following recommendations are suggested so as to enhance the role of the Suez Canal Corridor Project to support sustainable development:

a. Support having modifications in taxation and competition policy that can support the transition towards the circularity. Giving supportive tax reduction to industries wishing to locate in the project areas who avoid negative externalities can be effective.

b. Establish strict requirements in terms of sustainability for companies wishing to locate on the port and its industrial area to overcome the possible resistance during the transition towards a circular economy model. Authorities can make clear agreements with the companies regarding the air quality and negative externalities as studied from the case of the port of Rotterdam.

c. Support having indicators of progress those take into account the sustainability of that growth in an environmental and social context. Indicators like CO2 emissions and the percentage of waste to output can be effective measures in addition to the traditional existing indicators.

d. Modernization of related legislative and regulations framework to support the transition towards circularity. Putting into consideration avoid either regulating too much, or regulating the wrong things in good faith. Publishing a Circular Economy package, consisting of proposals for waste and environmental legislation can be an effective action.

e. Enhancing having markets for recycled materials.

f. Supporting investments in circular innovation.

g. Adopting a cultural change policy to attract stakeholders to believe that adopting a circular economy model could have significant economic impacts.

h. Integrate the circular economy model principles in education and training programs such as including system thinking and the awareness about the circular economy model in education.

\section{References}

Allen, C. and Clouth, S. (2012). A guidebook to the green economy. Issue 1: Green economy, green growth and low carbon development - history, definitions and a guide to recent publications, UN Division for Sustainable Development, Department of Economic and Social Affairs (UN-DESA): New York.

Beaulieu L., G. V. Durme and M. L. Arpin. (2015). Circular Economy: A Critical Review of Concepts, International Reference Centre for the Life Cycle of Products, Processes and Services, CIRAIG White Paper, retrieved from http://fliphtml5.com/aars/pult

Circular Economy System Diagram. (2015, November 16). Retrieved from

http://www.ellenmacarthurfoundation.org/circular-economy/interactive-diagram

El-Asmar, H. M., M. N. Taha, S. B. El-Kafrawy and A. S. El-Sorogy. (2015). Control of Late Holocene Geoprocesses on the sustainable development plans of the Tineh Plain. NW Sinai coast, Egypt. Journal of Coastal Conservation 19, 141-156.

Friedman, E. J., \& Oren, S. S. (1995). The complexity of resource allocation and price mechanisms under bounded rationality. Econ Theory Economic Theory, 6(2), 225-250. doi:10.1007/bf01212489

Gerarden, T., Newell, R., \& Stavins, R. (2015). An Assessment of the Energy-Efficiency Gap. HKS Faculty Research Working Paper Series, rwp15-004. Harvard University, John F. Kennedy School of Government.

Gillingham, K., R. G. Newell, and K. Palmer (2009). Energy Efficiency Economics and Policy. NBER Working Paper No. 15031, National Bureau of Economic Research.

Girard, L. F. (2013). Toward a Smart Sustainable Development of Port Cities/Areas: The Role of the Historic Urban Landscape Approach. Sustainability 5, 4329-4343.

Growth within: a circular economy vision for a competitive Europe. (2015). Ellen MacArthur Foundation, retrieved from 
https://www.ellenmacarthurfoundation.org/assets/downloads/publications/EllenMacArthurFoundation_G rowth-Within_July15.pdf

Hawken, P. (1997). Natural capitalism, Mother Jones retrieved from

http://www.paulhawken.com/multimedia/motherjones_naturalcapitalism.pdf

Hiranandani V. (2012, September). Sustainable development in the maritime industry: a multi-case study of seaports. Paper presented at World Economics Association (WEA) Conferences, No. 2 2012, Sustainability - Missing Points in the Development Dialogue, 24th September to 21 st October, 2012.

Jacobs, M (2012). Green Growth: Economic Theory and Political Discourse. Centre for Climate Change Economics and Policy Working Paper, 108 / Grantham Research, Institute on Climate Change and the Environment Working Paper No. 92.

Kippenberger, T. (2012). The Port of Rotterdam and Maasvlakte 2. The Best Management Practice, retrieved from

https://www.axelos.com/CMSPages/GetFile.aspx?guid=19aef1c7-0f80-483a-a26c-ac29bac2b706.

Kok., L., Wurpel, G. and Ten Wolde, A. (2013). Unleashing the Power of the Circular Economy. Report by IMSA Amsterdam for Circle Economy, retrieved from http://www.circle-economy.com/wp-content/uploads/2014/12/unleashing_the_ power_of_ the_circular_economy-circle_economy.pdf

Merk, O. (2013). The Competitiveness of Global Port-Cities: Synthesis Report. Paris: OECD Publishing.

Merk, O. and Dang, T. (2013). The Effectiveness of Port-City Policies; a comparative approach. OECD Regional Development Working Papers, 2013/25. OECD Publishing, Paris.

Porter, M.E. and Kramer, M.R (2006). Strategy and society: The link between competitive advantage and corporate social responsibility. Harvard Business Review, 84(12), 78-92.

Preston, F. (2012). A Global Redesign? Shaping the Circular Economy. Chatham House, Briefing Paper, EERG BP 2012/02, retrieved from

http://www.chathamhouse.org/sites/files/chathamhouse/public/Research/Energy, Environment and Development/bp0312_preston.pdf

Rizos V., A. Behrens, T. Kafyeke, M. Hirschnitz-Garbers and A. Ioannou (2015). The Circular Economy: Barriers and Opportunities for SMEs. CEPS working document no. 412.

Shi, L., Y. Dong and Z. Wu (2015). Dynamics of circular economy in China: illustration on the industrial port area of Ningbo. In Y. Alix, N. Mat and J. Cerceau (Eds.), Circular economy and port ecosystems (pp. 297-306).

Stahel W. R. (1997). The functional Economy: Cultural and Organizational Change. In Richards, Deanna J. (Eds.), The industrial Green Game, National Academy Press, Washington DC. (pp 91-100).

Stegeman H. (2015). From circular materials cycles to a circular macroeconomy with scenario's for the Netherlands. Rabobank Special, retrieved from

https://economics.rabobank.com/publications/2015/july/the-potential-of-the-circular-economy/

Strand J., \& Toman, M. (2010). "Green Stimulus," Economic Recovery, And Long-Term Sustainable Development. Policy Research Working Papers, 5163. doi:10.1596/1813-9450-5163.

Walendowski J., L.Roman and M.Miedzinski (2014). Regions in transition towards a circular economy. Thematic paper, Regional Innovation Monitor Plus, retrieved from

http://www.clubofrome.org/wp-content/uploads/2016/03/The-Circular-Economy-and-Benefits-forSociety.pdf 